\title{
Tipoexm SWorld
}

Берлявский Д.Т., Кочеткова О.В., Орлов М.М. и др.

\section{ПЕРСПЕКТИВНЫЕ ТРЕНДЫ РАЗВИТИЯ НАУКИ: МЕНЕДЖМЕНТ, ЮРИСПРУДЕНЦИЯ}

входит в РИНЦ SCIENCE INDEX

присвоен DOI: 10.21893/978-966-2769-90-6.0

\section{МОНОТРАФИЯ}


ББК 94

П 278

Авторский коллектив:

Берлявский Л.Г. (7.), Кочеткова О.В. (6.), Орлов М.М. (1., 2.), Ковтун Т.А. (4.), Селиванов А.В. (5.), Толбатов А.В. (8.), Толбатов В.А. (8.), В'юненко О.Б. (8.), Сфанов В.А. (8.), Смоляров Г.А. (8.), Тимошенко Д.В. (3.), Валяровский Ф.И. (7.), Васильев М.П. (6.), Коваленко И.А. (5.)

\section{Рецензенты:}

Тхабисимова Людмила Аслановна, доктор юридических наук, профессор, Пятигорский государственный университет

Куи Юрій Олексієвич, доктор наук з державного управління професор, Харківський інститут державного управління НАДУ при Президентові України

Руденко С.В., д.т.н., профессор, ОНМУ

Садовникова Н.П., д.т.н., профессор, Волгоградский государственный технический университет

Ведерникова Ольга Яковлевна, к.э.н., доцент, ЗАО ЗК "Северная"

П 278 Перспективные тренды развития науки: менеджмент, юриспруденция.: монография / [авт.кол. : Берлявский Л.Г., Кочеткова О.В., Орлов М.М. и др.]. - Одесса: КУПРИЕНКО СВ, 2016 - 204 с. : ил., табл.

ISBN 978-966-2769-90-6

Монография содержит научные исследования авторов в области менеджмента и юриспруденции. Может быть полезна для руководителей, экономистов, менеджеров, юристов и других работников предприятий и организаций, а также представителей органов государственной власти и местного самоуправления, преподавателей, соискателей, аспирантов, магистрантов и студентов высших учебных заведений.

УДК 001.895

ББК 94

DOI: 10.21893/978-966-2769-90-6.0

ISBN 978-966-2769-90-6

(C) Коллектив авторов, 2016

(C) Куприенко С.В., оформление, 2016 


\section{Монограбия подготовлена авторским коллективом:}

1. Берлявский Леонид Гарриевич, Пятигорский государственный лингвистический университет, Международного и европейского права, доктор исторических наук, профессор - ГЛАВА 7. (в соавторстве)

2. Кочеткова Ольга Владимировна, Волгоградский государственный аграрный университет, Кафедра: "Информационные системы и технологии", доктор технических наук, профессор - ГЛАВА 6. (в соавторстве)

3. Орлов Микола Михайлович, Національна академія Національної гвардії України, доктор наук государственного управления, доцент - ГЛАВА 1 , ГЛАВА 2

4. Ковтун Татьяна Антоновна, Одеський національний морський університет, Системный анализ и логистика, кандидат технических наук, доцент ГЛАВА 4.

5. Селиванов Анатолий Васильевич, Сибирский государственный аэрокосмический университет, кандидат технических наук, доцент ГЛАВА 5. (в соавторстве)

6. Толбатов Андрій Володимирович, Сумський національний аграрний університет, кафедра Кібернетики та інформатики, кандидат технических наук, доцент - ГЛАВА 8. (в соавторстве)

7. Толбатов Володимир Аронович, Сумський державний університет, кафедра Комп'ютерних наук, кандидат технических наук, доцент ГЛАВА 8. (в соавторстве)

8. В'юненко Олександр Борисович, Сумський національний аграрний університет, кафедра Кібернетики та інформатики, кандидат экономических наук, доцент - ГЛАВА 8. (в соавторстве)

9. Сфанов Володимир Анатолійович, Сумський національний аграрний університет, кандидат экономических наук, доцент ГЛАВА 8. (в соавторстве)

10.Смоляров Геннадій Андрійович, Сумський національний аграрний університет, кафедра Електротехнічних систем та фізики, кандидат экономических наук, доцент - ГЛАВА 8. (в соавторстве)

11.Тимошенко Дмитро Віталійович, Івано-Франківський національний технічний університет нафти і газу, Кафедра менеджменту і адмініструваня, кандидат экономических наук, доцент - ГЛАВА 3.

12.Валяровский Федор Иванович, Пятигорский государственный лингвистический университет, Международного и европейского права, кандидат юридических наук, доцент - ГЛАВА 7. (в соавторстве)

13.Васильев Максим Петрович, Волгоградский государственный аграрный университет, кафедра: "Информационные системы и технологии", специалист, ст. преп - ГЛАВА 6. (в соавторстве)

14.Коваленко Иван Андреевич, СибГАУ, кафедра логистики, магистрант ГЛАВА 5. (в соавторстве) 


\section{Содержание}

\section{ГЛАВА 1. ОБГРУНТУВАННЯ НЕОБХІДНОСТІ СТВОРЕННЯ ЄДИНОГО ОРГАНУ УПРАВЛІННЯ РЕГІОНАЛЬНИХ СИЛ ОХОРОНИ ПРАВОПОРЯДКУ}

Вступ.

1.1. Передумови можливих сумісних дій силових структур

в регіоні держави за єдиним замислом і планом.......................

1.2. Державницькі підходи до обгрунтування розширеного поняття

"регіональні сили охорони правопорядку"........................... 15

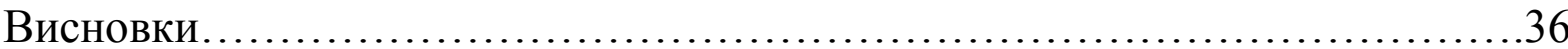

\section{ГЛАВА 2. МЕТОДОЛОГІЧНІ ПРОБЛЕМИ КІБЕРНЕТИЧНОГО МОДЕЛЮВАННЯ І ЛОГІКО-МАТЕМАТИЧНОГО ОПИСУ \\ ПРОЦЕСІВ ДЕРЖАВНИЦЬКОГО УПРАВЛІННЯ РЕГІОНАЛЬНИМИ СИЛАМИ ОХОРОНИ ПРАВОПОРЯДКУ}

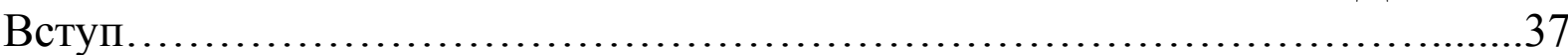

2.1. Роль уряду по зміцненню регіональних сил охорони правопорядку.......37

2.2. Методологічні питання кібернетичного моделювання процесів общедержавного управління регіональних сил охорони

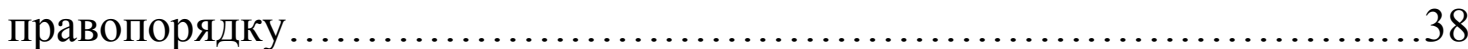

2.3. Можливості регіональних сил охорони правопорядку ...................41

2.4. Моделювання регіонального розподілу сил поліцейських на певні цілі...........................................................4 47

2.5. Шляхи інтеграції розвідувальної інформації в інтересах регіональної влади з боку правоохоронних органів....................51

2.6. Застосування кібернетичного моделювання і логіко-математичного опису процесу державного управління з боку регіональних правоохоронних сил в випадку завдання прикриття державного кордону України.

Висновки

\section{ГЛАВА З. МОДЕЛЬ СУЧАСНОГО МЕНЕДЖЕРА ЯК ІНСТРУМЕНТ РОЗВИТКУ ЙОГО ІНТЕЛЕКТУАЛЬНО-РЕСУРСНОГО ПОТЕНЦАЛУ}

Вступ..... 68

3.1. Огляд останніх досліджень у публікацій, в яких започатковано розв'язання даної проблеми на які спирається автор....................68

3.2. Виділення невирішених раніше частин загальної проблеми, яким присвячуються розвідки.

3.3. Постановка задачі з викладом матеріалу дослідження....................70

Висновки................................................................. 91

\section{ГЛАВА 4. СОВРЕМЕННЫЕ ПОДХОДЫ К УПРАВЛЕНИЮ ПРОЕКТАМИ}

Введение

4.1. Характеристика научных работ по применению современных управленческих и эволюционных подходов к проектам.

4.2. Особенности применения современных управленческих и эволюционных подходов к проектам. 
Выводы

ГЛАВА 5. ПОСТРОЕНИЕ ПОДСИСТЕМЫ УПРАВЛЕНИЯ ТРАНСПОРТНОЙ ЛОГИСТИКОЙ РАСПРЕДЕЛИТЕЛЬНОГО СКЛАДА

Введение

5.1. Особенности коммерческой деятельности распределительного склада.

5.2. Планирование параметров процесса междугородних перевозок грузов распределительного склада.

5.3. Планирование параметров процесса внутригородских перевозок грузов распределительного склада

5.4. Создание локального контура управления транспортной логистикой распределительного склада..

Выводы

\section{ГЛАВА 6. ОНТОЛОГИЧЕСКИЙ ИНЖИНИРИНГ В РАЗРАБОТКЕ ИТ-СТРАТЕГИИ}

Введение

6.1. Анализ теоретических исследований и практических подходов к разработке ИТ-стратегии.

6.2. Анализ моделей представления знаний специалиста в области стратегического планирования ИТ.

6.3. Оценка целесообразности применения онтологии для разработки

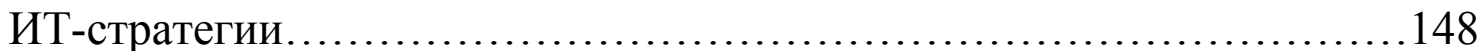

Выводы

\section{ГЛАВА 7. АКТУАЛЬНЫЕ ПРОБЛЕМЫ ТЕОРИИ И ПРАКТИКИ ЮРИДИЧЕСКОЙ ОТВЕТСТВЕННОСТИ В СОВРЕМЕННОМ МЕЖДУНАРОДНОМ ПРАВЕ}

Введение.

7.1. Теория и практика международно-правовой ответственности государств..................................................... 154

7.2. Теория и практика международно-правовой ответственности должностных лиц государства..........................................161

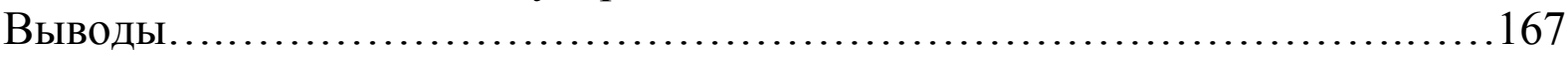

\section{ГЛАВА 8. АКТУАЛЬНІ ПРОБЛЕМИ ЗАБЕЗПЕЧЕННЯ ІНФОРМАЦИЙНОЇ БЕЗПЕКИ ЯК ФУНКЦІЇ СУЧАСНОЇ ДЕРЖАВИ}

Вступ.................................................................. 170

8.1. Правові засади забезпечення інформаційної безпеки....................170

8.2. Класифікаційна характеристика забезпечення інформаційної безпеки........................................................... 173

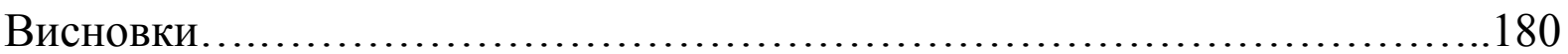

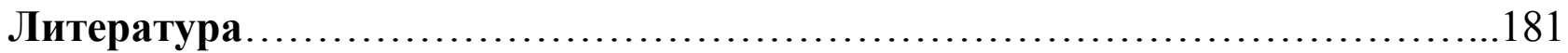




\section{Aumepamypa}

\section{Глава 1:}

1. Орлов М. М. Методичні підходи щодо визначення характеристик регіону держави / М. М. Орлов //Системи озброєння і військова техніка. Вип. 1(1). - Х. : Харк. ун-т Повітряних Сил, 2005. - С. 72-78.

2. Орлов М. М. Методичні підходи щодо обгрунтування структури регіонального органу управління силами охорони правопорядку // Пріоритетні напрямки підвищення ефективності діяльності правоохоронних структур i військових формувань України: Матеріали науково-практичної конференції / М. М. Орлов. - Хмельницький, Нац. акад. ДПСУ, 2007. - 54-55 с.

3. Орлов М. М. Теоретичні основи обгрунтування необхідності удосконалення системи управління регіональних сил охорони правопорядку (Теоретичні викладки до дисертаційної роботи) / М. М. Орлов. - Х. : Акад. внутрішніх військ МВС України, 2009. - 42 с.

4. Засімов В.П. Управління та організація діяльності у сфері цивільного захисту: практичний посібник. / В. П. Засімов, В. П. Садковий, Л. В. Ушаков. Х. : Ун-т. цивільн. захисту України, 2006. - 370 с.

5. Людские потери в конфликтах, кризах, войнах в 1945-1997 годах. Справочные данные //Зарубежное военное обозрение. - М. : «Красная звезда», 2004. - № 9. - C. 21-24.

6. Орлов М. М. Практична реалізація методу зонного поетапного параметричного аналізу і синтезу структури системи управління регіональних сил охорони правопорядку. Тези доповіді на п'ятій науковій конференції Харківського університету Повітряних Сил "Новітні технології - для захисту повітряного простору" / М. М. Орлов. - Х. : Харк. ун-т Повітряних Сил, 2009. C. $220-221$.

7. Корниенко М. В. Деятельность органов внутренних дел по обеспечению правопорядка при сложной оперативной обстановке (по материалам МВД Украины): монография. / М. В. Корниенко. - М. : Моск. ин-т МВД России, 2002. $-202 \mathrm{c}$.

8. Орлов М. М. Про необхідність створення єдиної системи управління регіональних сил охорони правопорядку. Тези доповіді на науково-практичній конференції Університету цивільного захисту України “Шляхи підвищення ефективності управлінської діяльності на сучасному етапі розвитку українського суспільства" 30-31 березня 2007 р. / М. М. Орлов. - Х. : Акад. цивільного захисту України, 2007. - С. 12-13.

9. Шмаков О. М. Словник офіцера внутрішніх військ з воєнно-наукових 
питань /О. М. Шмаков. - Х. : Військ. ін-т внутрішніх військ МВС України, 2004. $-244 \mathrm{c}$.

10. Орлов М. М. Методичні підходи щодо оптимізації чисельного складу і структури єдиного органу управління регіональних сил охорони правопорядку. Тези науково-практичної конференції Академії внутрішніх військ МВС України "Наукове забезпечення службово-бойової діяльності внутрішніх військ МВС України” / М. М. Орлов. - Х. : Акад. внутрішніх військ МВС України, 2009. C. 20-22.

11. Орлов М. М. Методика комплексної оцінки доцільної структури органів управління відкритих систем керування / М. М. Орлов, О. В. Перепелиця // Зб. наук. праць ХВУ. Вип. 2 (45). - Х. : Харк. військ. ун-т, 2003.C. $40-45$.

12. Орлов М. М. Про необхідність і напрями удосконалення регіональної системи управління внутрішніх військ. Тези доповіді на науково-практичній конференції. / М. М. Орлов. - Х. : Акад. внутрішніх військ МВС України, 2008. - C 18-20.

13. Орлов М. М. Комплексна методика аналізу системи управління силами охорони правопорядку / М. М. Орлов // Честь і закон - 2009 - № 2. - Х. : Акад. внутрішніх військ МВС України, - С. 26-39.

14. Орлов М. М. Комплексна методика синтезу системи управління силами охорони правопорядку / М. М. Орлов // Честь і закон - 2010 - № 1. - Х. : Акад. внутрішніх військ МВС України, - С. 26-39.

15. Орлов М. М. Модель формування регіональних органів управління сил охорони правопорядку / М. М. Орлов // Честь і закон № 2. - Х. : Акад. внутрішніх військ МВС України, 2008. - С. 28-34.

16. Орлов М. М. Метод визначення рівня повноважень єдиного органу управління регіональних сил охорони правопорядку шляхом ранжування управлінських завдань / М. М. Орлов // Честь і закон. - Х. : Акад. внутрішніх військ МВС України. - № 2. - 2010. - С. 46-54.

17. Орлов М. М. Методичні основи реалізації можливостей органів управління військового призначення: монографія / М. М. Орлов. - Х. : Акад. внутрішніх військ МВС України, 2007. - 369 с.

18. Орлов М. М. Методика визначення показника якості роботи органу управління встановленої структури / М. М. Орлов // Системи озброєння і воєнна техніка. Вип. 1 (9). - Х. : Харк. ун-т Повітряних Сил, 2007. - С. 56-60.

19. Орлов М. М. Роль і місце начальника управління територіального командування внутрішніх військ, як керівника регіонального органу управління 
військами із складу регіональних сил охорони правопорядку / М. М. Орлов // Наукове забезпечення службово-бойової діяльності внутрішніх військ МВС України: зб. тез доповідей наук.-практ. конф., Харків, 17-18 березня 2010 р. Х. : Акад. внутрішніх військ МВС України, 2010. - С. 54-55.

20. Орлов М. М. Напрямки автоматизації пунктів управління регіональної системи управління сил охорони правопорядку / М. М. Орлов // Честь і закон № 3. - Х. : Акад. внутрішніх військ МВС України, 2007. - С. 75-84.

21. Низиенко Б. И. Методы автоматизации управления подготовкой Войск ПВО к боевому применению / Б. И. Низиенко, К. А. Метешкин, А. В. Сисков //Збірник наукових праць ХВУ. Вип. 1(39) - Х.: Харк. військ. ун-т, 2002. - С. $46-50$.

22. Городнов В. П. і ін. Моделювання бойових дій військ (сил) протиповітряної оборони та інформаційне забезпечення процесів управління ними (теорія, практика, історія розвитку): монографія. - Х.: Харк. військ. ун-т, 2004. $-410 \mathrm{c}$.

23. Орлов Н. М. Факторы, влияющие на достоверность информации о воздушной обстановке / Н. М. Орлов, В. П. Лысечко, Д. А. Пархоменко. //Збірник наукових праць ХВУ. Вип. 5(43). Х.: Харк. військ. ун-т, 2002.- С. 322 325.

24. Голубко Б. В. Концептуальні питання удосконалення єдиної АСУ ППО України на основі НІТ / Б. В. Голубко // Збірник наукових праць ЦНДІ МОУ №1, 1998. - С. 24-26.

25. Назієнко Б. І. Концептуальні основи створення перспективної АСУ протиповітряною обороною і авіацією Збройних Сил України / Б. I. Назієнко, С. А. Войнович, М. В. Грачов, О. С. Бодяк // Системи озброєння і військова техніка № 2 (2). - Х.: Харк. ун-т Повітряних Сил, 2005. - С. 75-79.

26. Іващук В. О. Напрями подальшого розвитку зв'язку і АСУ Збройних Сил України // Наука і оборона - 1999. № 1. / В. О. Іващук. - К.: Мін. оборони України, 1999. - С. 13-18.

\section{Глава 2:}

1. Бир. Ст. Кибернетика в управлении производством [Текст] / Ст. Бир. М. : Наука, 1965. - 391 с.

2. Бакуменко В. Д. Загальні моделі діяльнісного підходу як інструмент дослідження суб'єкт-об'єктних відносин [Текст] / В. Д. Бакуменко // Науковий вісник. Зб. наук. праць. Серія "Управління”. - К. : Акад. муніципального упр., 2012. Вип. 2/2012. - С. 6-19. 
3. Коршунов Ю. М. Математические основы кибернетики : учеб. пособ. [Текст] / Ю. М. Коршунов. - М. : Энергоатомиздат, 1987. - 496 с.

4. Державне управління в Україні: наукові, правові, кадрові та організаційні засади: навчальний посібник [Текст] // За загальною редакцією Н. Нижник та В. Олуйка. - Львів, 2002. - 353 с. ISBN 966-553-265-0.

5. Райт Г. Державне управління. Пер. 3 англ. [Текст] / Г. Райт. - К. : Основа, 1994. - 432 с.

6. Гурне Б. Державне управління [Текст] / Бернар Гурне ; пер. с фр. B. Шовкун. - К. : Основи, 1993. -164 с.

7. Миколайчук 3. Решение проблем в управлении [Текст] / 3. Миколайчук; пер. с польск. - Х. : Гуманитарный центр, 2004. - 472 с.

8. Ожегов С. И. Словарь русского языка. [Текст] / С. И. Ожегов. - М. : Рус. яз., 1983. $-816 \mathrm{c}$.

9. Заморин А. П. Толковый словарь по вычислительной технике и программирование: основные термины [Текст] / А. П. Заморин, А. С. Марков. К. : Изд-во КСХА, 1989. - 221 с. ISBN 5-7987-0024-0.

10. Бонарев В. А. Кибернетика в военном деле [Текст] / В. А. Бонарев. - М. : Воениздат, 1968. - 288 с.

11. Орлов, М. М. Принципи корпоративної поведінки посадових осіб регіональних органів державної влади в Україні [Текст] / М. М. Орлов // Тези доповіді на Всеукраїнській науково-практичній конференції “Державне управління в контексті адміністративної реформи” 17-18 грудня 2015 р. Маріуполь: Донецький державний університет управління; аналітичноінформаційний журнал “Схід”, 2015. - С. 124-127.

12. Моисеев, Н. Н. Экология человека глазами математика [Текст] / Н. Н. Моисеев. - М. : Молодая гвардия, 1988. - 252 с.

13. Эшби У. Р. Введение в кибернетику [Текст] / У. Р. Эшби. - М. : Иностранная литературы, 1959. - 432 с.

14. Orlov, N. M. State position on the existing contradictions of operational staff as governing body of modern regional law enforcement forces. Теорія і практика правознавства 1(2016) - X. : Нац. юрид. ун-т ім. Ярослава Мудрого. [Електронний ресурс]. Режим доступу DOI: http://dx.doi.org/10.21564/22256555.2016.1.68911. ISSN-2225-6555. - C. 3-12.

15. Закон України про Національну гвардію України [Текст] (ВВР, 2014, № 17, ст. 594.

16. Загальна характеристика поняття [Електрон. ресурс]. - Режим доступу : http://pidruchniki.com/15970122/logika/ponyattya. 
17. Большая Советская Энциклопедия в 30 томах [Текст]. - М. : Советская энциклопедия, 1975.

18. Державні стандарти України ДСТУ В 3265-95.

19. Орлов,М. М. Формування системи взаємодії регіональних органів виконавчої влади у сфері охорони правопорядку (теоретико-методологічні засади) [Текст] : монографія / М. М. Орлов. - Х. : ХарРІ НАДУ “Магістр”, 2012. - 344 c. ISBN978-966-390-112-1.

20. Орлов М. М. Порядок формування органів управління силових структур [Текст] / М. М. Орлов // Теорія та практика державного управління : зб. наук. праць. - Х. : ХарРІ НАДУ “Магістр”, 2011. - Вип. 4 (35). - С. 77-85.

21. Научные ответы на вызовы современности: менеджмент, юриспруденция: [моногр.] / И. Я. Львович, Н. М. Орлов, А. П. Приображенский и др Одесса, Куприенко С. В., 2016. - 164 c.ISBN 978-966-2769-77-7.

22. Орлов, Н. М. Обоснование состава сил охраны общественного порядка и их распределения в сложных условиях [Текст] / М. М. Орлов // Современный научный вестник (научно-теоретический и практический журнал): серия: Право. Политология. Белгород, Россия. - № 9 (205), $2014 . \quad$ - С. 60-69.

23. Орлов, Н. М. Применение переносных блочных многоярусных заградительных препятствий для использования силами охраны общественного порядка [Текст] / М. М. Орлов, О. І. Шаповалов // Менеджмент и маркетинг : Сб. науч. тр. SWorld. T. 3.Технические науки - Одесса, 2014. Проект SWorld международной наукометрической базы РИНЦ SCTENCE INDEX. - C. 20-30.

24. Орлов М. М. Порядок формування організаційно-інформаційних систем військового призначення [Текст] / М. М. Орлов, Р. О. Гончар. // Честь i закон. - Х. : Акад. ВВ МВС України, 2011. - Вип. 4. - С.15-29.

25. Малышев В. Н. Передача информации в АСУ / В. Н. Малышев, Ю. В. Осипов. - Л. : Воен.-морск. акад., 1984. - 286 с.

26. Браславец М. Е. Кибернетика / М. Е. Браславец, Т.Ф. Гуревич. - К. : «Вища школа», 1977. - 325 с.

27. Метешкин К. А. Кибернетическая педагогика. Теоретические основы управления образованием на базе интегрированного интеллекта: монография / К. А. Метешкин. - Х. : Межнар. Словян. ун-т, 2004. - 400 с. ISBN966-7383-288.

28. Бережна С. М. Вплив інформаційних технологій на реорганізацію військової справи США на початку XXI століття [Електрон. ресурс]. - Режим доступу : http://chitalka.net.ua/textbooks/1/p 4945.html

29. Szafranski R. Harnessing Battlefield Technology: Neocortical Warfare: The 
Acme of Skill, Military Review. - November 1994.

30. Szafranski, R. Parallel War and Hyperwar: Is Every Want a Weakness? Chapter 5 in Air Chronicles compilation on Battlefield of the Future. - March 1996.

31. Hanp.Haeni R.E. Information Warfare. An Introduction. - The George Washington University. -Washington DC. A - Jan. 1997.

32. Morrison P. Walker P.F. A New Strategy for Military Spending. Scientific American. Vol.239. - No.4.- October 1978.

33. Від початку антитерористичної операції на сході України минув один рік [Електрон. ресурс]. - Режим доступу:

http://www.radiosvoboda.org/content/news/26952789.html.

34. Тероризм у розвинених країнах. [Електрон. ресурс]. - Режим доступу: http://newsradio.com.ua/2013 05 23/Terorizm-u-rozvinenih-kra-nah-Dov-dka/.

35. Анатолій Розанов. Білорусь: вектори зовнішньої політики. [Електрон. pecypc]. - Режим доступу: http://www.ji.lviv.ua/n18texts/rozanov.htm.

36. В Європі почались навчання НАТО. [Електрон. ресурс]. - Режим доступу: http://www.informator.news/v-evropi-pochalys-navchannya-nato/.

37. Orlov, N. M. State going near a necessity and directions of the centralized planning of points for the tactical link of management of the National household troops of Ukraine. Научный журнал «Власть и общество» (История, теория, практика) 1(37) 2016. ISSN-1512-374 Х. - Грузия. г. Тбилиси. Грузинский техн. ун-т, 2016. - С. 28-39.

38. Орлов М. М. Обгрунтування напрямів автоматизації системи управління військами Національної гвардії України / M. М. Орлов // Международное научное издание. Научные труды SWorld. Вып. № 3 (36). T. 17. Менеджмент и маркетинг - Одесса, 2014. - С. 99-108.

39. Народний броньований КАМАЗ [Електронний ресурс]. Режим доступу: http://www.peoplesproject.com/kamaz/.

40. Багатоканальний електрозв'язок та телекомунікаційні технології: підручник / За редакцією Поповського В. В. - Х. : “Компанія СМІТ”. 2003. $512 \mathrm{c}$.

\section{Глава 3:}

1. В режиме самосохранения. Спецпроект [Текст] // Комп\&ньоН. - 2015. 一 № $17-18$. - С. $16-27$.

2. Внутренние секреты успеха компаний [Електронний ресурс] // СТРАТЕГИИ. - 2002. - № 2. - Електрон. текст. дані. - Режим доступу: http://www.strategy.com.ua/Articles/Content?Id=170, вільний (дата звернення: 
01.03.2016). - Заголовок з екрана. - Мова рос.

3. Тимошенко Д. В. Деякі міркування про побудову структури сучасної інтелектуальної організації [Текст] / Д. В. Тимошенко // Инновационные технологии управления. В 2 книгах. К 1. : монография / [авт.кол. : Баранников А.А., Дунская А.Р., Ильиных С.А. и др.]. — Одесса: КУПРИЕНКО СВ, 2013 C. $32-49$.

4. Петренко В. П. Модель мотиваційного простору організаційного утворення як основа розробки стратегії мотивації ії персоналу [Текст] / В. П. Петренко, М. О. Табахарнюк // Науковий вісник ІФНТУНГ. — 2002. — № 2 (3). - C. $100-106$.

5. Христич А. Эмоциональное и интеллектуальное участие [Текст] / А. Христич // Комп\&ньоН. - 2012. - № 33-34. - С. 22-23.

6. Мельник Д. Куда идти, чтобы идей найти [Текст] / Д. Мельник // Комп\&ньоН. — 2007. — №1-2. - С. 31-34.

7. Мельхиседек Д. Древняя Тайна Цветка Жизни [Текст] / Д. Мельхиседек. Пер. с англ. под. ред. И. В. Сутокской. - Том 1. - К. : «София»; М. : ИД «София», 2003. - 248 с.

8. Ястреб А. Разыскивается стратегия роста [Текст] / А. Ястреб // \&.СТРАТЕГИИ. - 2011. - № 4. - С. 48-51.

9. Тимошенко Д. В. Щодо шляхів удосконалення просторової мотиваційної моделі формування команди 3 пріоритетом інтелектуальних досягнень [Текст] / Д. В. Тимошенко, В. П. Петренко // Наукові вісті інституту менеджменту та економіки «Галицька академія». — 2008. — №2 (14). - С. 97-102.

10. Внутренние секреты успеха компаний [Електронний ресурс] // СТРАТЕГИИ. - 2002. - № 2. - Електрон. текст. дані. - Режим доступу: http://www.strategy.com.ua/Articles/Content?Id=170, вільний (дата звернення: 01.03.2016). - Заголовок з екрана. - Мова рос.

11. Пачковський Ю.Ф. Психологія підприємництва. Навчальний посібник [Текст] / Пачковский Ю. Ф. - Львів, 2001. - 276 с.

12. Dunkin, R. Motivating knowledge workers : lessons to and from the corporate sector [Текст] / R. Dunkin // Higher education management \& policy. 2003. - Vol. 15. - № 3. - P. $41-49$.

13. Щеглова К. Чем озадачены маркетологи и рекламисты мира [Текст] / К. Щеголова // Комп\&ньоН. - 2015. — № 7. - С. 36-38.

14. Stiehm J. U.S. Army War College: Military Education In A Democracy [Текст] / J. Steihm. — Philadelphia : Temple University Press, 2002. — 260 p. 
15. Flamholtz E. Towards Using Organizational Measurements to Assess Corporate Cerformance [Текст] / Eric G. Flamholtz // Journal of Human Resource Costing \& Accounting. — 2009. — Vol. 13 (Iss: 2). — pp. 105-117.

16. Полная функция управления на Руси и в США : об этике и управленческом профессионализме [Електронний документ] // О текущем моменте. — 2009. — № № 4-5 $(88,89)$. — С. 126. / Електрон. текстові дані $(1$, 64 Мб). - Систем. вимоги: Windows 95/98/ME/NT4/2000/XP/Vista. Adobe Acrobat reader. - Заголовок 3 титул. екрану. - Режим доступу: http://dotu.ru/files/20090528 tek moment0589.pdf . - Мова poc.

17. Мескон М. Основы менеджмента : Пер. с англ. [Текст] / М. Мескон, М. Альберт, Ф. Хедоури ; Общ. ред. и вступ. ст. Л. И. Евенко. - 3-е изд. - М. : Дело, 2000. — 704 с.

18. Mascon M. Management [Текст] / M. Mascon, M. Albert, F. Khedouri. Harlow : Pearson Education Limited, «LONGMAN», 1988. — 777 p.

19. Hartzell S. Four Functions of Management: Planning, Organizing, Leading \& Controlling / S. Hartzell. [Електрон. текст. дані]. - Режим доступу: http://study.com/academy/lesson/four-functions-of-management-planning-

organizing-leading-controlling.html, потрібна реєстрація (дата звернення: 01.03.2016). - Заголовок з екрана. - Мова англ.

20. Петренко В.П. Тактика особистої роботи менеджера (персональний менеджмент) [Текст] / В. П. Петренко, М. О. Данилюк, А. В. Попадюк, М. О. Табахарнюк. - Івано-Франківськ, 1996. - 188 с.

21. Доорн П. Ещё раз о методологии: старое и прекрасное: «мыльная опера» о непонимании между историками и моделями [Текст] / П. Доорн // Новая и новейшая история. - 1997. — № 3. - С. 88-102.

22. Пригожин И. Порядок из хаоса : Новый диалог человека с природой [Текст] / И. Пригожин, И. Стенгерс ; пер. с англ. / общ. ред. В. И. Аршинова, Ю. Л. Климонтовича и Ю. В. Сачкова. - М. : Прогресс, 1986. - 432 с.

23. Шалобаев Е. В. Теоретические и практические проблемы развития мехатроники [Текст] / Е. В. Шалобаев // Современные технологии: Сборник / Под ред. С. А. Козлова. - СПб : ГИТМО (ТУ), 2001. - С. 46-66.

24. Лагутина Г. С. О простоте и сложности [Текст] / Г. С. Лагутина // Конверсия в машиностроении. - 1994. — № 4. - С. 50-51.

25. Рогожкин В. Ю. Эниология [Текст] / В. Ю. Рогожкин. - Р. : ЭНИО, 2002. $-544 \mathrm{c}$.

26. Кубайчук А. «Минное поле» логотипа [Електронний ресурс] / А. Кубайчук // Комп\&ньоН. - 2003. - № 21. - Режим доступу до сайту: 
http://www.i-see.ru/articles/articles/struktura.htm, (11.01.2013). - Заголовок 3 екрану. - Мова рос.

27. Хинтон Ч. Г. Четвертое измерение и Эра новой мысли [Текст] / Ч. Г. Хинтон. - Петроград : Книгоиздательство «Новый человек», 1915. - 258 с.

28. Еко У. Маятник Фуко [Текст] / У. Еко. Пер. 3 італійської Мар'яни Прокопович. - Львів : Літопис, 2004. - 652 с.

29. Lauby S. 6 Qualities In a Leadership Role Model [Текст] / S. Lauby. Електрон. текст. дані.

Режим доступу: https://www.hrbartender.com/2013/leadership-and-management/6-qualities-in-aleadership-role-model/, вільний (дата звернення: 01.03.2016). — Заголовок 3 екрана. - Мова англ.

30. Greenleaf R. The Servant as Leader [Текст] / R. Greenleaf. - Indianapolis, IN : The Greenleaf Center for Servant Leadership, 2015. - $64 \mathrm{p}$.

31. Tolle, E. The power of now: a guide to spiritual enlightenment [Текст] / E. Tolle. - Novato. : New World Library, 2004. — 235 p.

32. Берн Э. Игры, в которые играют люди: психология человеческих отношений. Люди, которые играют в игры : психология человеческой судьбы [Текст] / Э. Берн. - М. : Эксмо, 2006. - 566 с.

33. Берн, Э. Лидер и группа : о структуре и динамике организаций и групп [Текст] / Э. Берн ; пер. с англ. А. Грузберга. - М. : Эксмо, 2009. - 512 с.

34. Соболева, Е. Предприниматель - Ребёнок или Взрослый? [Текст] / Е. Соболева // СТРАТЕГИИ. — 2013. — № 3. - С. 54-56.

35. Курченко Л. Будущее уже началось [Електронний ресурс] / Л. Курченко // Комп\&ньоН. - 2008. - № 9. - Електрон. текст. дані. - Режим доступу: http://www.companion.ua/articles/content?id=19087, вільний (дата звернення: 01.03.2016). — Заголовок з екрана. — Мова рос.

36. Тимошенко Д. В. Інтелектуальна праця: особливості та актуальні завдання з управління мотивацією [Текст] / Д. В. Тимошенко // Сборник научных трудов SWorld. Материалы международной научно-практической конференции «Перспективные инновации в науке, образовании, производстве и транспорте `2012». - Выпуск 2. Том 25. — Одесса : КУПРИЕНКО, 2012. - С. $49-62$.

37. Джейкобс Ч. Нейроменеджмент. Почему не работает мотивация методом кнута и пряника [Текст] / Ч. Джейкобс ; пер. с англ. — К. : Companion Group, 2010. — 208 c.

38. Шупбах М. Эволюционное лидерство [Текст] / М. Шупбах // \&.СТРАТЕГИИ. - 2010. — № 9. - С. 40-41. 
39. Мороз Н. Лидерство в стиле джаз [Текст] / Н. Мороз, П. Шеремета // \&.СТРАТЕГИИ. - 2003. - № 6. - Режим доступу до журн.: http://www.strategy.com.ua/article.aspx?column=1\&article=203. (Перевірено 13.08.2016). - Назва з екрану. — Мова рос.

40. Най Д. Гибкая сила. Как добиться успеха в мировой политике [Текст]/ Джозеф Най. - М. : Тренд, 2006. - 397 с.

41. Manager/Supervisor's Role In Change Management. - Електрон. текст. дані. - Режим доступу: https://www.prosci.com/change-management/thoughtleadership-library/manager-change-management-role , вільний (дата звернення: 01.03.2016). - Заголовок з екрана. — Мова англ.

42. Кісь Г. Р. Щодо оптимізації освітнього менеджменту в сфері підготовки кадрів для нафтогазових підприємств i організацій в рамках Болонського процесу [Текст] / Г.Р. Кісь, Д.В. Тимошенко // Науковий вісник Івано-Франківського національного технічного університету нафти і газу. Серія : «Економіка та управління в нафтовій і газовій промисловості». Вип. 1 (11). Редкол.: голов. ред. В. П. Петренко. - Івано-Франківськ, 2015. - С. 15-25.

43. Филиповкая Ю. Фасилитация. Профессия XXI века стара как мир [Текст] / Ю Филиповская // \&.СТРАТЕГИИ. - 2015. — № 1. - С. 14-18.

44. Элзаккер Т. Создание прорывных продуктов [Текст] / Т. Єлзаккер // \&СТРАТЕГИИ. - 2011. - № 11. - С. 19-26.

45. Тимошенко Д. В. Мотиваційний механізм управління інтелектуальною працею персоналу нафтогазових підприємств та організацій : автореф. дис. ... канд. екон. наук : 08.00.04 [Текст] / Д. В. Тимошенко. - Івано-Франківськ, 2011. - $20 \mathrm{c}$.

46. Василишин Н. С. До уточнення поняття «інтелектуальний ресурс» 3 метою адекватної оцінки і врахування в процедурах стратегічного планування економічного розвитку регіональних соціально-економічних систем [Текст] / Н. Є. Василишин, Д. В. Тимошенко, І. В. Фіщук, В. П. Петренко // Соціальноекономічні дослідження в перехідний період. Інноваційно-інвестиційне забезпечення стратегії розвитку регіону (Збірник наукових праць). Вип. 5 (61) / НАН України. Ін-т регіональних досліджень. Редкол.: відп. ред. акад. НАН України М. І. Долішній. - Львів, 2006 - С. $250-258$.

47. Тимошенко Д. В. Огляд тестового інструментарію діагностики мотивованості людських ресурсів соціально-економічних систем [Текст] / Д. В. Тимошенко // Наукові вісті інституту менеджменту та економіки «Галицька академія». - 2007. — № 1 (11). - С. 205-209.

48. Калина, Н. Ф. Вопросник самоактуализации личности [Текст] / Н. Ф. 
Калина // Журнал практического психолога. - 1998. - № 1. - С. 65-75.

49. Виявлення особистісних обмежень ефективного управління. Методичні матеріали до лабораторної роботи з предметів психолого-педагогічного циклу для слухачів інженерно-технічних та економічних спеціальностей / Склад Ю. В. Вінтюк. — Львів, 2000. - 18 с.

\section{Глава 4:}

1. Колтынюк Б. А. Инвестиционные проекты : учебн. / Б. А. Колтынюк. СПб.: Изд-во Михайлова В. А., 2000. - 422 с.

2. Пинто Дж. К. Управление проектами / Дж. К. Пинто ; пер. с англ. В. Н. Футова. - СПб. : Питер, 2004. - 464 с.

3. Кобиляцький Л. С. Управління проектами : навчальн. посібник. / Л. С. Кобиляцький. - К. : МАУП, 2002. - 200 с.

4. Тян Р. Б. Управління проектами : підруч. / Р. Б. Тян, Б. І. Холод Б.І., В. А. Ткаченко. - К.: Центр навчальної літератури, 2003. - 224 с.

5. Мазур И. И. Управление проектами : учебн. пособие / И. И. Мазур, В. Д. Шапиро, Н. Г. Ольдерогге. - М. : ОМЕГА - Л, 2004. - 405 с.

6. Бушуев С. Д. Модели и методы стратегического развития организаций от «видения» к реальности / С. Д. Бушуев, Н. С. Бушуева // Управління проектами та розвиток виробництва. - 2005. - № 4. - С. 5-13.

7. Рогальский Ф. Б. Математические методы анализа экономических систем / Рогальский Ф. Б., Курилович Я. Е., Цокуренко А. А. - К. : Наукова думка, 2001. - 435 с.

8. Антоненко С. В. «Маленькі відкриття» замість великого працелюбства, або Засоби оцінювання в управлінні проектами. Частина 3. Склад систем та його використання для побудови списку робіт проекту / С. В. Антоненко // Управління проектами та розвиток виробництва. - 2006. - № 1. - С. 50-54.

9. Ребенок А. В. Синергетична концепція стратегічного управління проектами / А. В. Ребенок // Управління проектами та розвиток виробництва. 2005. - №2. - С. 30-36.

10. Малый В. В. Новации на протяжении жизненного цикла проекта / В. В. Малый, Ю. В. Сивопляс // Управління проектами та розвиток виробництва. 2005. - № 4. - C. 45-50.

11. Махуренко Г. С. Анализ внешней среды окружения проекта / Г. С. Махуренко, О. Н. Степанов // Управління проектами та розвиток виробництва. - 2002. - № 1. - C. 99-105.

12. Рач В. А. Стратегический потенциал предприятия в условиях новой 
экономики / В. А. Рач // Управління проектами та розвиток виробництва. 2002. - № 1. - С. 5-9.

13. Дорош М. С. Управління процесом формування програм інноваційного розвитку регіонів / М. С. Дорош, І. В. Калінько, А. В. Ребенок // Управління проектами та розвиток виробництва. - 2006. - № 1. - С. 129-136.

14. Бушуев С. Д. Современные подходы к развитию методологий управления проектами / С. Д. Бушуев, Н. С. Бушуева // Управління проектами та розвиток виробництва. - 2005. - № 1. - С. 5-19.

15. Бушуев С. Д. Введение в международную систему сертификации профессиональных проектних менеджеров. Структура и содержание сертификационного экзамена IPMA / С. Д. Бушуев. - К. : Украинская Ассоциация Управления проектами, 1998. - С.1-6.

16. Рач В. А. Принципи системного подхода в проектном менеджменте / В. А. Рач // Управління проектами та розвиток виробництва. - 2000. - № 1. - С.79.

17. Керівництво з основ Проектного менеджменту. Інститут проектного менеджменту США. - К. : ВІПОЛ, 1999. - 197 с.

18. Колесников Л. А. Основы теории ситемного подхода / Л. А. Колесник. - К. : Наукова думка, 1988. - 176 с.

19. Литвинченко А. А. Проблемы развития науки управления проектами / А. А. Литвинченко, В. А. Рач // Управління проектами та розвиток виробництва. - 2004. - № 4. - С. 5-12.

20. Бурименко Ю. И. Структурные модели предпроектного исследования сложных систем / Ю. И. Бурименко // Управління проектами та розвиток виробництва. -2000 . - № 1. - С. 62-65.

21. Бушуев С. Д. Проактивное управление программами организационного развития / С. Д. Бушуев, Н. С. Бушуева // Управління проектами та розвиток виробництва. - 2006. - № 2. - С. 22-30.

22. Воронкова А. Э. Стратегическое управление конкурентоспособным потенциалом предприятия (диагностика и организация) : [монография] / А. Э. Воронкова. - Луганск : Изд-во Восточноукраинского университета, 2000. - 315 c.

23. Лапкина И. А. Полимодельный подход к обоснованию проектов развития судоходного предприятия / И. А. Лапкина, Е. Л. Семенчук // Управління проектами та розвиток виробництва. - 2004. - № 4. - С. 13-23.

24. Бабаев И. А. Формирование генетического кода проекта как инструмента навигации по его жизненному пути / И. А. Бабаев, С. Д. Бушуев, 
Н. С. Бушуева // Управління проектами та розвиток виробництва. - 2005. - № 2. - C. $5-11$.

25. Бушуев С. Д. Развитие систем знаний и технологий управления проектами / С. Д. Бушуев // Управление проектами. - М. : Издательский дом Гребенникова. -2005 . № 2. - С. 18-24.

26. Подолинський С. А. Вибрані твори / С. А. Подолинський. - К. : КНЕУ, 2000. $-328 \mathrm{c}$.

27. Вернадський В. И. Живое вещество / В. И. Вернадский. - М. : Наука, 1978. -358 c.

28. Кондратьев Н. Д. Избранные сочинения : [в 2-х кн.] / Н. Д. Кондратьев. - М. : Экономика, 1993.

29. Реймерс Н. Ф. Природопользование : словарь-справочник / Н. Ф. Реймерс. - М. : Мысль, 1990. - 637 с.

30. Иноземцев В. Л. За пределами экономического общества. Постиндустриальные теории и постэкономические тенденции в современном мире / В. Л. Иноземцев. - М. : Academia-Наука, 1988. - 640 с.

31. Стелюк Б. Б. Применение биологического подхода к развитию организации / Б. Б. Стелюк // Управління проектами та розвиток виробництва. - 2004. - № 4. - С. 142-145.

32. Стелюк Б. Б. Совершенствование диагностики объектов направлений организационных изменений / Б. Б. Стелюк // Управління проектами та розвиток виробництва. - 2005. - № 1. - С. 119-128.

33. Мильнер Б. 3. Теория организации / Б. 3. Мильнер. - М. : ИНФРА-М, 2001. $-558 \mathrm{c}$.

34. Щекин Г. В. Практическая психология менеджмента. Как делать карьеру. Как строить организацию. : научно-практич. пособ. / Г. В. Щекин. - К. : Україна, 1994. - 399 с.

35. Стелюк Б. Б. Организационные изменения как инструментальная основа развития предприятия / Б. Б. Стелюк // Управління проектами та розвиток виробництва. - 2005. - № 2. - С. 153-157.

36. Антоненко С. В. «Маленькі відкриття» замість великого працелюбства, або Засоби оцінювання в управлінні проектами. Частина 2. Розвиток систем та явища які його супроводжують / С. В. Антоненко, В. В. Малий, О. І. Мазуркевич // Управління проектами та розвиток виробництва. - 2003. - № 3. C. $34-41$.

37. Чугуевец С. С. Принятие решений в традиционной и новой экономике: сравнительный анализ / С. С. Чугуевец // Управління проектами та розвиток 
виробництва. - 2002. - № 1. - С. 86-89.

38. 58 науково-технічна конф. : збірник тез допов., 17-19 трав. 2005 р., Одеса / відп. за вип. В. В. Олейніков. - Од. : Вид-во ОНМУ, 2005. - 95 с.

39. Сивопляс Ю. В. Перспективы внутренних иннованций проекта / Ю. В. Сивопляс // Управління проектами та розвиток виробництва. - 2006. - № 2. C. $114-118$.

40. Винер Н. Кибернетика и общество / Н. Винер. - М. : Иностр. л-ра, 1958. $-200 \mathrm{c}$.

41. Кобринский Н. Е. Основы экономической кибернетики / Н. Е. Кобринский. - М. : «Экономика», 1969. - 255 с.

42. Кобринский Н. Е. Введение в экономическую кибернетику / Н. Е. Кобринский, Е. 3. Майминас, А. Д. Смирнов. - М. : «Экономика», 1975. - 343 с.

43. Коршунов Ю. М. Математические основы кибернетики / Ю. М. Коршунов. - М. : «Энергия», 1972. - 376 с.

44. Снапелев Ю.М. Моделирование и управление в сложных системах / Ю. М. Снапелев, В. А. Старосельский. - М. : «Советское радио», 1974. - 264 с.

45. Рыбак А. И. Теория управления в управлении проектами / А. И. Рыбак, П. Д. Федунец // Управління проектами та розвиток виробництва. - 2004. - № 2. - С. $77-81$.

46. Федунец П. Д. Проектне керування системою з управлінням / П. Д. Федунец // Управління проектами та розвиток виробництва. - 2004. - № 4. - С. $45-50$.

47. Солоп Е. Г. Особенности функционирования параллельных структур в организациях с жесткими структурно-функциональными ограничениями / Е. Г. Солоп // Управління проектами та розвиток виробництва. - 2004. - № 4. - С. 90-99.

48. Василєвська Т. П. Розв'язок задачі стратегічної оптимізації управління / Т. П. Василєвська // Управління проектами та розвиток виробництва. - 2004. №4. - С. 110-117.

49. Анфилатов В. С. Системный анализ в управлении : учебн. пособие / Анфилатов В. С., Смельянов А. А., Кукушкин А. А. - М. : Финансы и статистика, 2003, -368 с.

50. Товб А. С. Управление проектами : стандарты, методы, опыт / А. С. Товб, Г. Л. Ципес. - М. : ЗАО «Олимп-Бизнес», 2003. - 240 с.

51. Лапкина И. А. Проблемы применения процессного подхода в деятельности коммерческих и некоммерческих организаций / И. А. Лапкина // Управління проектами та розвиток виробництва. - 2006. - № 2. - С. 62-71. 
52. Капитанов В. П. Процессы управления в проектах / В. П. Капитанов // Методи та засоби управління розвитком транспортних систем : збірн. наук. праць. - 2004. - № 8. - С. 112-127.

53. Модели управления проектами в нестабильной экономической среде / [Ю. Г. Лысенко, А. П. Белый, В. В. Гнатушенко и др.]. - Донецк: ООО «ЮгоВосток, Лтд», 2003. - 292 с.

54. Блех Ю. Инвестиционные расчеты. Модели и методы оценки инвестиционных проектов / Ю. Блех, У. Гетце ; пер. с нем. - Калининград: «Янтарный сказ», 1997. - 438 с.

55. Рач В. А. Особенности взаимодействия руководителя и команды на различных этапах проекта / В. А. Рач, С. В. Антоненко, Г. С. Черепаха // Управління проектами та розвиток виробництва. - 2004. - № 1. - С. 160-170.

56. Мазуркевич А. И. Управление на основе общей модели развития систем // Управління проектами та розвиток виробництва. - 2005. - № 2. - С. $18-23$.

57. Лапкина И. А. Управление проектами : тексты лекций / И. А. Лапкина. - Од. : ОНМУ, 2002. - $131 \mathrm{c.}$

58. Бэгьюли Ф. Управление проектом / Ф. Бэгьюли ; пер.с англ. - М. : ФАИР-ПРЕСС, 2002. - 208 с.

59. Тарасюк Г. М. Управління проектами : навч. посіб. / Г. М. Тарасюк. К. : Каравела, 2004. - 344 с.

60. Болдырева Т. В. Применение интегрального метода факторного анализа результатов инвестиционной деятельности судоходной компании / T. В. Болдырева // Розвиток методів управління та господарювання на морскому транспорті : зб. наук. праць. - 1999. - № 5. - С. 106-117.

61. Бабаев I. А. Інноваційна технологія в управлінні програмами розвитку організацій на основі генетичної моделі проекту : автореф. дис. на здобуття наук. ступеня доктора техн. наук: спец. 05.13.22 «Управл. проект. та прогр.» / I. А. Бабаев. - К., 2006. -41 с.

62. Грин Н. Биология : в 3-х т. / Грин Н., Стаут У., Тейлор Д. : пер. с англ. [ред. Р.Сопер]. Т.3. - М. : Мир, 1990.- 376 с.

63. Управління проектами в умовах глобалізації знань : тези допов. III міжнар. конф. [«Управління проектами у розвитку суспільства»], (Київ, 2006 р.) / МОНУ, КНУБА, УАУП, АУП, відП. ред. С. Д. Бушуєв. - К. : КНУБА, 2008. $176 \mathrm{c}$.

64. Машина Н. I. Економічний ризик та методи його вимірювання : навч. посібн. / Н. І. Машина. - К. : Центр навчальної літератури, 2003. - 188 с. 
65. Гранатуров В. М. Экономический риск : сущность, методы, измерения, пути снижения / В. М. Гранатуров. - М. : Дело и Сервис, 1999. - 109 с.

66. Стасюк В. П. Риск и адаптивные качества ПЭС : ризикологія в економіці та підприємництві / В. П. Стасюк. - К. : КНЕУ, 2001. - С.384-386.

67. Риск-анализ инвестиционного проекта : учебн. [для вузов] / [ред. М. В. Грачева]. - М. : ЮНИТИ-ДАНА, 2001. - 351 с.

68. Анфилатов В. С. Системный анализ в управлении : учебн. пособие / Анфилатов В. С., Смельянов А. А., Кукушкин А. А. - М. : Финансы и статистика, 2003, -368 с.

69. Бусленко Н. П. Моделирование сложных систем / Н. П. Бусленко. Главная редакция физико-математической литературы изд-ва «Наука», 1978. $399 \mathrm{c}$.

70. Квейд Э. Анализ сложных систем / Э. Квейд. - М. : Сов. Радио, 1969. $518 \mathrm{c}$.

71. Калашников В. В. Сложные системы и методы их анализа / В. В. Калашников. - М. : Знание, 1980. - 64 с.

72. Советский энциклопедический словарь / [гл. ред. А.М. Прохоров]. - М. : Советская энциклопедия, 1990. - 1632 с.

73. Мельник Л. Г. Информационная экономика / Л. Г. Мельник. - Сумы : ИТД «Университетская книга», 2003. - 288 с.

74. Словник іншомовних слів / [ред. О. С. Мельничук]. - К. : Головна редакція української радянської енциклопедії, 1977. - 776 с.

75. Управління програмами організаційного розвитку в конкурентном отченні : тези допов. IV міжнар. конф. [«Управління проектами у розвитку суспільства»], (Київ, 2007 р.) / МОНУ, КНУБА, УАУП, АУП, відп. ред. С. Д. Бушуєв. - К. : КНУБА, 2007. - 174 с.

76. Управління проектами : стан та перспективи : тези допов. III міжнар. наук.-практ. конф., (Миколаїв, 2007 р.) / МОНУ, НУК, АНСУ, УАУП та інші, відп. ред. К. В. Кошкін. - К. : НУК, 2007. - 299 с.

77. Орловский П. Н. Системный анализ. Основные понятия, принципы, методология : учебн. пособие / П. Н. Орловский. - К. : ИСМО, 1996. - 360 с.

78. Большая Советская Энциклопедия. - М. : Советская энциклопедия, т. 21, 1975. $-409 \mathrm{c}$.

79. Болдырева Т. В. Методика оценки эффективности инвестиционного проекта с учетом ситуаций риска / Т. В. Болдырева, Т. А. Ковтун // Методи та засоби управління розвитком транспортних систем : збірн. наук. праць. -2003. - № 6 . - C. 237-255. 
80. Болдырева Т. В. О целесообразности принятия инвестиционного проекта с учетом риска / Т. В. Болдырева, Т. А. Ковтун // Управління проектами та розвиток виробництва. - 2003. - № 3. - С. 46-55.

81. Кабардин О. Ф. Физика : справочные материалы [учебн. пособие] / О. Ф. Кабардин. - М. : Просвещение, 1991. - 368 с.

82. Мельник Л. Г. Фундаментальные основы развития / Л. Г. Мельник. Сумы : ИТД «Университетская книга», 2003. - 288 с.

83. Ожегов С. И. Толковый словарь русского языка : Российская академия наук. Институт русского языка им. В.В.Виноградова / С. И. Ожегов, Н. Ю. Шведова. - М. : А ТЕМП, 2004. - 944 с.

84. ICB - IPMA Competence Baseline. Version 2.0. IPMA Editorial Committee. - Bremen : Eigenverlag, 1999. - p. 23.

85. ISO/TR 10006: 1997 (E). Quality Management - Guidelines to quality in project management. - p. 1 .

86. AIPM - Australian Institute for Project Management, National Competence Standard for Project Management - Guidelines 1996. - p.18.

87. British Standard BS 6079-1:2000. Project Management - Part 1: Guide to Project management, p.2.

88. National Competence Baseline, NCB UA Version 3.0.

89. Тернер Дж. Р. Руководство по проектно-ориентированному управлению / Дж. Р. Тернер ; пер. с англ., [ред. В. И. Воропаев]. - М. : Издательский дом Гребенникова, 2007. - 552 с.

90. Международный стандарт ИСО 9001. Системы менеджмента качества. Требования ; пер. с англ. - М. : НТК Трек, 2001. - 33 с.

91. Бушуев С. Д. Современные подходы к развитию методологий управления проектами / С. Д. Бушуев, Н. С. Бушуева // Управління проектами та розвиток виробництва. - 2005. - № 1. - С. 5-19.

92. Ковтун Т. А. Некоторые особенности генетического подхода управлению проектами / Т. А. Ковтун // Управління проектами та розвиток виробництва. - 2007. - № 3. - С. 46-57.

93. Ковтун Т. А. Методический подход к принятию управленческих решений по инициализации продуктов проекта транспортного предприятия / Т. А. Ковтун // Управління проектами та розвиток виробництва. - 2007. - № 2. C. $145-157$.

\section{Глава 5:}

1. Селиванов А. В., Коваленко И. А. Совершенствование логистического 
обеспечения распределительного склада //Современные проблемы экономического и социального развития: Межвузовский сборник научных трудов, посвящённых памяти проф. Г.С. Михалёва.- Красноярск: Изд-во СибГАУ,2015. - Вып. №11. С.128-131.

2. Селиванов А. В., Коваленко И. А., Вашлаев И. И. Инструментарий планирования параметров логистических процессов распределительного склада [Электронный ресурс] // Решетневские чтения: материалы XIX Междунар. науч.- практ. конф., посвящ. 55-летию Сиб. гос. аэрокосмич. ун-та им. акад. М. Ф. Решетнева (10-14 нояб. 2015, г. Красноярск) : в 2 ч. /под общ. ред. Ю. Ю. Логинова ; Сиб. гос. аэрокосмич. ун-т. - Красноярск, 2015. - Ч. 2. - С. 410 - 412. URL: https://disk.sibsau.ru/index.php/s/uDJa2yNrAKVal8g/download.

3. Дроздов П. А. Распределительные центры в цепях поставок//Логистические системы и процессы в современных экономических условиях: материалы Международной заочной научно-практической конференции (1-15 ноября 2013 г.): сборник статей/ Министерство образования Республики Беларусь [и др.]. - Минск: Национальная библиотека Беларуси, 2013. - C. 55 - 67.

4. Григорьев М.Н., Долгов А. П., Уваров С.А. Логистика. Продвинутый курс: учеб. - М.: Юрайт, 2014. - 734c.

5. Дыбская В. В. Логистика складирования: учебник. - М.: ИНФРА-М, 2015. - $559 \mathrm{c}$.

6. Фёдоров Л.С., Персианов В.А., Мухаметдинов И.Б. Общий курс транспортной логистики: учеб. пособ. - 2-е изд., стер.- М.: КНОРУС, 2016.$310 \mathrm{c}$.

7. Тяпухин А.П. Логистика: учеб. для бакалавров. - 2-е изд. перераб. и доп.М.: Изд-во Юрайт, 2013.- 568c.

8. Селиванов А.В. Особенности контурно-интегрированного управления логистическими процессами промышленного предприятия// Логистика: современные тенденции развития: материалы XIV Междунар. науч.практ. конф. 9-10 апреля 2015г.: материалы докл./ отв. ред. В.С. Лукинский.СПб.: ГУМРФ им. адмирала С.О. Макарова, 2015. С.315-317.

9. Селиванов А.В., Бурменко Р.Р. Контурно-интегрированное управление процессами логистической системы промышленного предприятия// Современный менеджмент: опыт прошлого и перспективы будущего: глава в коллективной монографии (включена в наукометрическую базу РИНЦ Science index)/ [авт. кол.: Васьков М.А., Фадеева И.Г., Сапицкая И.К., Селиванов А.В. и др.].- Одесса: Изд-во КУПРИЕНКО СВ, 2015. - С. 30 - 53; 189 - 191. 
10. Селиванов А.В., Шамлицкий Я.И. Транспортно-складская логистика производственной системы машиностроительного предприятия // Вестник СибГАУ. - 2013. - Вып. 2(48). - С. 260-265.

11. Р. С. Каплан, Д. П. Нортон Сбалансированная система показателей От стратегии к действию. М.:Олимп-Бизнес Букс. 2008. - 214c.

12. Хьюберт К., Рамперсад. Внедрение сбалансированной системы показателей/ Horvath \& Partners; Пер. с нем. М.: Альпина Бизнес Букс, 2005. $478 \mathrm{c}$.

13. Селиванов А.В., Прокопович Д.А., Вашлаев И.И. Сбалансированная подсистема показателей возвратной логистики промышленного предприятия//Вестник СибГАУ. 2014. Вып. 1(53). С. 218-225.

14. Селиванов А. В., Бурменко А. Д. Рейтинговые оценки как фактор распознавания экономических нарушений в сфере промышленного производства//Национальная безопасность: региональные аспекты приграничья: сб. докладов Международной очно-заочной научно-практической конференции (20-21 февраля 2014г., г. Чита).- Чита: Изд-во Забайкальского государственного университета,2014.С. 75-77.

15. Селиванов А.В. Факторный анализ воздействия логистических затрат на технико-экономические показатели предприятия //Менеджмент в России и за рубежом. 2016. №2. С. 99-106.

16. Дыбская В. В. Логистика: Учебник/В.В.Дыбская, Е.Н.Зайцева, В.И.Сергеев и др.- М.:Эксмо, 2011.-944с.

17. Лукичёва Л. И., Егорычев Д. Н. Управленческие решения: учеб. пособ. - М.: Омега-Л, 2006,- 383c.

18. Афанасьев А. Г. Человек: общество, управление, информация. Опыт системного подхода. - М.: Книжный дом «ЛИБРОКОМ», 2013. - 208c.

19. Филина Ф.Н. Настольная книга менеджера по логистике: учебное пособие / Ф.Н.Филина. - Гросс Медиа Издательство, 2009. - 272 с.

20. Концепция формирования информационной основы карьера / В.А. Падуков, А.В. Селиванов, М.Л. Медведев, И.И. Вашлаев //ФТПРПИ, 1993. -№4 - C. 67-73.

\section{Глава 6:}

1. ИТ-консультант Холодков Антон [Электронный ресурс] / ИТ-стратегия, часть 1-я: общий стратегический процесс в организации. - Режим доступа: http://www.kholodkov.ru/it/?p=671 свободный.

2. Кочеткова О.В., Васильев М.П. ИТ-стратегия как основа для системного 
внедрения информационных технологий в сфере ДПО // Интеграция систем дополнительного и основного профессионального образования как фактор повышения конкурентоспособности специалистов АПК / Материалы Международной научно-практической конференции, Волгоград, 24-26 мая 2010 г. - Волгоград: ИПК ФГОУ ВГСХА «Нива», 2010. - С. 70-77.

3. Alexander Velikiy Personal Blog [Электронный ресурс] / Разработка ИТстратегии - Режим доступа: https://alexandervelikiy.com/tag/it-strategy/ свободный.

4. Искусство бега по граблям. Стратегическое управление ИТ в условиях неопределенности / Зеленков Ю. А. - М., 2013. - 32 с.

5. Competing in the Information Age: Align in the Sand. Jerry N. Luftman (ed.), NY, Oxford U Mueller-Eberstein, M. (2010) Agility. Competing and Winning in a TechSavvy Marketpalce. Hoboken, NJ, Wiley

6. Mueller-Eberstein, M. (2010) Agility. Competing and Winning in a TechSavvy Marketpalce. Hoboken, NJ, Wiley

7. Методика обеспечения устойчивости стратегии развития информационных технологий на предприятии в условиях неопределенности воздействия среды / Кузькин А. А. - О., 2015. - 32 с.

8. Большая онлайн библиотека [Электронный ресурс] / Целостная модель знания специалиста и рынок знания предприятия - Режим доступа: http://www.e-reading.club/chapter.php/144771/34/Telemtaev___Celostnyii_metod__teoriya_i_praktika.html свободный.

9. Разработка метода и средств представления модели знаний в задачах автоматизированной конструкторско-технологической подготовки производства / Елисеева Н. В. - М., 2007.

10. T.R.Gruber. A translation approach to portable ontologies. Knowledge Acquisition, 5(2):199-220, 1993.

11. Базы знаний интеллектуальных систем / Т. А. Гаврилова, В. Ф. Хорошевский - СПб: Питер, 2000. — 384 с.

12. Saaty, T., 1993, "Decision-Making. Analytic Hierarchy Process," Moscow, Radio and Communication, 320 p

13. Использование моделей инженерии знаний для подготовки специалистов в области информационных технологий / Т. А. Гаврилова, И. А. Лещева, Д. В. Кудрявцев // Системное программирование. Том7. - СанктПетербург, 2012. - с. 90-105

14. Мухин С. П., Методика выбора ИПИ технологий / Минэкономпром РТ, 2004 г. 


\section{Глава 7:}

1. Международное право: Учебник. / Под ред. Ю. М. Колосова, В. И. Кузнецова. - М.: Международные отношения, 2006. - 636 с.

2. Международное право в документах. - М.: Международные отношения, 2014. - С 388.

3. Лукашук И. И. Право международной ответственности. - М.: Юристъ, 2004. $-253 \mathrm{c}$.

4. Берлявский Л. Г. Международное право. Словарь - справочник. - М.: Проспект, 2014. - 382 с .

5. Алексеев И. А. К вопросу об отличиях муниципально-правовой ответственности от иных видов юридической ответственности // Государственная власть и местное самоуправление. - 2016. - № 9.

6. Валяровский Ф. И. Конституционное право России и международное право. Актуальные проблемы взаимодействия. - Саарбрюкен: LAP Lambert Academic Pablishing, 2012. - 140 c.

7. Валяровский Ф. И. Международное право и новый мировой порядок в ХХІвеке. // Политическое пространство и социальное время. / Под ред. Т. А. Сенюшкиной, В. А. Баранова. - Симферополь: ИТ «АРИАЛ», 2016. - С. 37-40.

8. Международное публичное право. Сборник документов. Т. 2. - М: Международные отношения, 1996. - С. 101-102.

9. Сборник действующих договоров, соглашений и конвенций, заключенных СССР с иностранными государствами. Вып. XI. - М.: Наука, 1955. - C. 165-172.

10. Сборник действующих договоров, соглашений и конвенций, заключенных СССР с иностранными государствами. Вып. ХІІ. - М.: Наука, 1956. - C. 79-86.

11. Международный трибунал для судебного преследования лиц, ответственных за серьезные нарушения международного гуманитарного права, совершенные на территории бывшей Югославии с 1991г., учрежден резолюцией 827 (1993) Совета Безопасности от 25 мая 1993 г.

12. Международный уголовный трибунал для судебного преследования лиц, ответственных за геноцид и другие серьезные нарушения международного гуманитарного права, совершенные на территории Руанды, и граждан Руанды, ответственных за геноцид и другие подобные нарушения, совершенные на территории соседних государств, в период с 1 января 1994 г. по 31 декабря 1994 г. Учрежден тремя резолюциями Совета Безопасности ООН: № 955 от 8 ноября 1994 г. (S/RES/955 (1994), № 978 от 27 февраля1995 г. 
(S/RES/978 (1995), № 1165 от 30 апреля1998 г. (S/RES/1165 (1998).

13. Гуськова Е. Ю. Международный трибунал по бывшей Югославии: деятельность, результаты, эффективность. - М: Проспект, 2012. - 224 с.

14. Мезяев А. Б. Права обвиняемого в международном судебном процессе: автореф. дис... д-ра юрид. наук. Казань, 2013. - 46 с.

15. Rome Statute of the International Criminal Court, U.N.Doc A/Conf.183/9, July 17, 1998.

16. Измайлова П. Р. Уголовная ответственность должностных лиц государства за преступления по международному праву: автореф. дис... канд. юрид. наук. М., 2015. - 43 с.

17. Гайсс Р., Бюлинкс Н. Международные и интернационализированные уголовные трибуналы: синопсис // Международный журнал Красного Креста. 2006. - T. 88. - № 861. - С. 49-60.

18. Скуратова А. Ю. Международные преступления: современные проблемы квалификации. - М: Юнити-Дана, 2012. - 281 с.

19. Берлявский Л.Г. 65-летие Нюрнбергского процесса над главными нацистскими военными преступниками: уроки истории // Российская юстиция. - 2011. - № 10. - С. 57-61.

20. Берлявский Л. Г. Суд над нацистским правом. Нюрнбергский процесс: 65 лет спустя // Право и образование. - 2011. - № 6. - С. 146-156.

\section{Глава 8:}

1. Арістова I. В. Державна інформаційна політика: організаційно-правові аспекти: монографія / І.В. Арістова; -Х.: Вид-во Ун-ту внутр.справ, 2000.-368c.

2. Великий тлумачний словник сучасної української мови (з дод. і допов.) / [уклад. і голов. ред. В. Т. Бусел]. - К.; Ірпінь : ВТФ «Перун», 2005. - 1728 с.

3. Гусарєв С. Д. Юридична діяльність: методологічні та теоретичні аспекти / С. Д. Гусарєв. - К. : Знання, 2005. - 375 с.

4. Харченко Л. С. Інформаційна безпека України : глосарій / Л. С. Харченко, В. А. Ліпкан, О. В. Логінов ; [заг. ред. Р. А. Калюжний]. - К. : «Текст», 2004. - 134 с.

5. Про Доктрину інформаційної безпеки України : Указ Президента України №514/2009 від 08.07.2009.

6. Про Концепцію Національної програми інформатизації : Закон України №75/98-ВР від 04.02.1998.

7. Про Основи національної безпеки : Закон України №964-IV від 19.06.2003. 
8. Про інформацію : Закон України №2657-ХІІ від 02.10.1992.

9. Про затвердження переліку спеціальностей, за якими здійснюється підготовка фахівців у вищих навчальних закладах за освітньо-кваліфікаційними рівнями спеціаліста і магістра : Постанова Кабінету Міністрів України №787 від 27.08.2010.

10. Cybercrime training for judges and prosecutors: a concept [Електронний pecypc].http://www.coe.int/t/DGHL/cooperation/LisbonNetwork/meetings/Autre/207 9 train concept 4 provisional 8 oct09 en.pdf

11. Марущак А. І. Інформаційна безпека як об'єкт дослідження правової науки / А. I. Марущак // Актуальні проблеми управління інформаційною безпекою держави : зб. матер. наук.прак. конф., 17 березня 2010 року м. Київ. К. : Наук. вид. відділ НА СБ України, 2010. - С. 36-41.

12. Панченко В. М. Структурно-функціональний аналіз загальнодержавної системи забезпечення інформаційної безпеки / В. М. Панченко // Інформаційна безпека людини, суспільства, держави: наук.-практ.журн.-2009.-№ 1-С.48-51.

13. Про державну таємницю : Закон України №3855-XII від 21.01.1994.

14. Про доступ до публічної інформації : Закон України №2939-VI від 13.01.2011.

15. Тихомиров О. О. Класифікації забезпечення інформаційної безпеки / О. O. Тихомиров // Вісник Запорізького національного університету : Юридичні науки. - Запоріжжя : ЗНУ. - 2011. - №1. - С. 164-169.

16. Толбатов А. В. Автоматизовані інформаційні системи як ефективний засіб забезпечення прийняття управлінських рішень органами державної влади / А.В. Толбатов, В.О. Загорулько // Інформатика, математика, автоматика материалы НТК, 18-22 квітня 2016 р. - Суми : СумДУ, 2016. - С. 163.

17. Толбатов А.В. Комплексный подход к обеспечению информационной безопасности / А.В. Толбатов // Современные методы кодирования в электронных системах : материалы НТК, (23-24 апреля 2002 г.). - Сумы : СумГУ, 2002. - С. 56. 


\title{
ПЕРСПЕКТИВНЫЕ ТРЕНДЫ РАЗВИТИЯ НАУКИ: МЕНЕДЖМЕНТ, ЮРИСПРУ ДЕНЦИЯ
}

\author{
Aвmopbl: \\ Берлявский Л.Г. (7.), Кочеткова О.В. (6.), Орлов М.М. (1., 2.), \\ Ковтун Т.А. (4.), Селиванов А.В. (5.), Толбатов А.В. (8.), \\ Толбатов В.А. (8.), В'юненко О.Б. (8.), Сфанов В.А. (8.), \\ Смоляров Г.А. (8.), Тимошенко Д.В. (3.), Валяровский Ф.И. (7.), \\ Васильев М.П. (6.), Коваленко И.А. (5.)
}

Научные достижения Авторов монографии были также рассмотрены и рекомендованы для издания на международном научном Симпозиуме «ПЕРСПЕКТИВНЫЕ ТРЕНДЫ РАЗВИТИЯ НАУКИ»

(20-27 сентября 2016 г.) на сайте www.sworld.education

Монография включена в РИНЦ SCIENCE INDEX

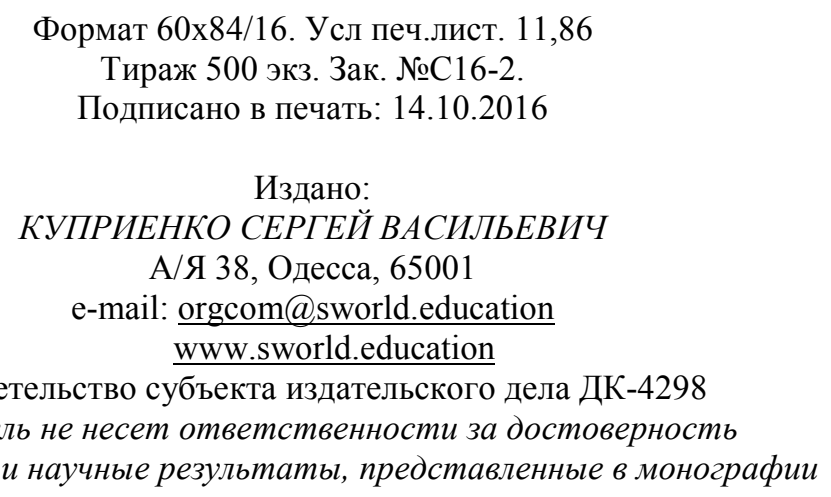

Отпечатано с готового оригинал-макета ФЛП Москвин А.А./ Цифровой типографии “Соpy-Art” г. Запорожье, пр. Ленина 109 